\title{
An analytical study on wound dehiscence and related factors
}

Shalini Mahana, Som Biswas*

Department of Obstetrics \& Gynecology, Grant Medical College \& Sir JJ group of Hospitals, Mumbai, Maharashtra, India

Received: 17 August 2013

Accepted: 5 September 2013

*Correspondence:

Dr. Som Biswas,

E-mail: sombiswas4@gmail.com

(C) 2013 Mahana S et al. This is an open-access article distributed under the terms of the Creative Commons Attribution Non-Commercial License, which permits unrestricted non-commercial use, distribution, and reproduction in any medium, provided the original work is properly cited.

\section{ABSTRACT}

Wound dehiscence is a significant cause of post operative morbidity. In this study the various factors associated with wound dehiscence were studied. All patients with wound dehiscence post gynecological surgeries in our hospital were evaluated retrospectively for possible risk factors. Major risk factors as per our study include malnutrition, obesity, illiteracy, low socioeconomic status, anemia, diabetes mellitus, blood transfusion, prolonged surgery, emergency procedures. Most of these factors were preventable or modifiable at a primary level.

Keywords: Wound dehiscence, Surgical morbidity, Scar healing.

\section{INTRODUCTION}

Success of a gynaecological procedure via an abdominal incision depends on careful selection of incision site \& proper closure of the wound. Surgeon needs to consider multiple factors like disease process, body habitués, operative exposure, simplicity, previous scars, cosmesis $\&$ the need for quick entry into abdominal cavity, as certain risk factors that play a role in increasing postoperative infections. Complications associated with surgical incisions range from annoying to lifethreatening, wound dehiscence being one of them. Maternal morbidity related to infection after caesarean section is 8 times higher than after vaginal delivery. Surgical site infection occurs within 30 days of incision even after discharge of the patient.

\section{Aims of the Study}

- To study various predisposing factors associated with wound dehiscence.

- To maximize chances of wound healing and minimize possibility of wounds dehiscence through simple measures.

\section{METHODS}

This is a retrospective study done over a period of one year in a tertiary care hospital in Mumbai, on patients undergoing major surgery, Caesarean Section, Total abdominal hysterectomy etc who had superficial wound dehiscence (skin \& subcutaneous tissue).

Demographic information \& indication were recorded. Host related variables included built (weight), socioeconomic status, education, hygiene, preoperative hemoglobin, associated medical conditions \& history of previous surgeries.

\section{RESULTS}

Total gynecological surgeries done in the specified period were 243 . Total no. of wound dehiscence were $42(17.28 \%)$. Out of 169 LSCS, 32 cases had wound dehiscence (18.9\%). Out of 74 TAH 10 cases had wound dehiscence $(13.5 \%)$. 
Table 1: Based on BMI (body mass index) of the patient the following data was obtained.

\begin{tabular}{|c|c|c|c|}
\hline & $\begin{array}{l}\text { Underweight } \\
\text { (less than } \\
18.5 \mathrm{~kg} / \mathrm{m} 2 \text { ) }\end{array}$ & $\begin{array}{l}\text { Normal } \\
(18.5 \text { to } \\
252 \mathrm{~kg} / \mathrm{m})\end{array}$ & $\begin{array}{l}\text { Overweight } \& \\
\text { Obese } \\
\text { (Greater than } \\
25 \mathrm{~kg} / \mathrm{m} 2)\end{array}$ \\
\hline $\begin{array}{l}\text { LSCS } \\
(n=32)\end{array}$ & $15(47 \%)$ & $9(28 \%)$ & $8(25 \%)$ \\
\hline $\begin{array}{l}\text { TAH (n } \\
=10)\end{array}$ & $1(10 \%)$ & $4(40 \%)$ & $5(50 \%)$ \\
\hline
\end{tabular}

$(\mathrm{LSCS}=$ lower segment Caesarean station, $\mathrm{TAH}=$ Total abdominal hysterectomy)

It can be concluded that tissues must be healthy to heal and both extremes of weight predispose to dehiscence.

Most women with wound dehiscence were from the lower socioeconomic strata.

Table 2: Socioeconomic status was calculated based on modified kuppuswamy scale.

\begin{tabular}{|l|l|}
\hline Upper socioeconomic strata & $\mathbf{4 ( 1 0 \% )}$ \\
\hline Middle & $9(21 \%)$ \\
\hline Lower & $29(69 \%)$ \\
\hline
\end{tabular}

Most women with wound dehiscence were illiterate. Literate meant those who can read and write with understanding.

Table 3: Comparison of literate \& illiterate.

\begin{tabular}{|c|c|}
\hline Literate & $15(36 \%)$ \\
\hline Illiterate & $27(64 \%)$ \\
\hline
\end{tabular}

Preoperative hemoglobin was measured and those who anemic had higher rates of wound dehiscence. Preoperative anemia is a major predictor of impending surgical morbidity.

Table 4: Preoperative haemoglobin.

\begin{tabular}{|ll|}
\hline Hemoglobin $(\mathrm{gm} \%)<\operatorname{logm} \%$ & $\mathbf{3 3}(\mathbf{7 8} \%)$ \\
\hline$>10 \mathrm{gm} \%$ & $9(22 \%)$ \\
\hline
\end{tabular}

Table 5: Pre, intra \& post-operative blood transfusion, all increase the chances of wound dehiscence.

\begin{tabular}{|lll|}
\hline $\begin{array}{l}\text { Blood Transfusion } \\
\text { (Pre, Intra \& Postop) }\end{array}$ & Yes & No \\
\hline LSCS(n=32) & $23(72 \%)$ & $9(28 \%)$ \\
\hline TAH $(n=10)$ & $8(80 \%)$ & $2(20 \%)$ \\
\hline
\end{tabular}

$(\mathrm{LSCS}=$ lower segment Caesarean station, $\mathrm{TAH}=$ Total abdominal hysterectomy)

Associated medical disorders increased the chances of wound dehiscence.

Out of 169 LSCS pts, 3 had diabetes mellitus all of which dehiscenced. Out of 74 TAH, 6 had diabetes mellitus \& out of which 4 dehiscenced. Good general health is necessary for wound healing.

There was no significant correlation between history of previous abdominal surgery and wound dehiscence.

From this Table 6: it can be concluded that associated medical disorders are more prone to wound dehiscence.

Table 6: History of previous abdominal surgery.

\begin{tabular}{|lll|}
\hline $\begin{array}{l}\text { History of previous } \\
\text { abdominal surgery }\end{array}$ & Yes & No \\
\hline LSCS $(\mathrm{n}=32)$ & $18(56 \%)$ & $14(44 \%)$ \\
\hline TAH $(\mathrm{n}=10)$ & $4(40 \%)$ & $6(60 \%)$ \\
\hline
\end{tabular}

(LSCS $=$ lower segment Caesarean station, TAH= Total abdominal hysterectomy)

Table 7: Planned surgery was associated with less wound dehiscence.

\begin{tabular}{|lll|}
\hline & Emergency & Elective \\
\hline $\operatorname{LSCS}(\mathrm{n}=32)$ & $30(94 \%)$ & $2(6 \%)$ \\
\hline $\operatorname{TAH}(\mathrm{n}=10)$ & Not Applicable & 10 \\
\hline
\end{tabular}

$($ LSCS $=$ lower segment Caesarean station, $\mathrm{TAH}=$ Total abdominal hysterectomy)

Duration of surgery was estimated. Surgery has to be learnt and in-experienced2 surgeons (e.g.: trainees in teaching hospitals) tend to take longer increasing the chance of wound-dehiscence.

Table 8: It can be concluded that less time in surgery are less prone to wound dehiscence.

\begin{tabular}{|ll|}
\hline$<1 \mathrm{hr}$ & $\mathbf{9}(21 \%)$ \\
\hline$>1 \mathrm{hr}$ & $33(79 \%)$ \\
\hline
\end{tabular}

Wound swab for culture was taken from all patients with wound dehiscence. 
$78 \%$ were sterile and rest was positive for staphylococcus aureus.

Table 9: It can be concluded that infection cannot be blamed for all wound dehiscence $\&$ there was need for limited antibiotics.

\begin{tabular}{|lc|}
\hline Sterile & $\mathbf{3 3 ( 7 8 \% )}$ \\
\hline $\begin{array}{l}\text { Positive } \\
\text { (Staphylococcus aureus) }\end{array}$ & $9(28 \%)$ \\
\hline
\end{tabular}

\section{DISCUSSION}

Wound dehiscence is multi-factorial. Major risk factors as per our study include malnutrition, obesity, illiteracy, low socioeconomic status, anemia, diabetes mellitus, blood transfusion, prolonged surgery, emergency procedures most of which cannot be influenced by the surgeon. We can derive that prevention is primary for reducing incidence of wound dehiscence. A good diet with education to maintain hygiene and early correction of anemia and diabetes will definitely help in bringing down the rate of dehiscence.

Patients who develop wound dehiscence are $60 \%$ more likely to spend time in an ICU. ${ }^{1}$ Five times as likely to be re-admitted \& have a morbidity rate twice that of noninfected patients. $^{2}$ Surgical site Infections are the third most frequently reported nosocomial infection, accounting for $14 \%$ to $16 \%$ of all nosocomial infections among hospitalized patients. ${ }^{3}$ Proper surgical attire, hand washing and theatre sterility are also important. Correct surgical techniques like removing all devitalized tissue, maintaining effective homeostasis, gentle handling of tissues, eradicating dead space, avoiding inadvertent entries into a viscous, using drains and suture material appropriately. Duration of prophylactic antibiotic administration should not exceed the 24-hour postoperative period as we saw that positive wound culture is not majorly found.

Also medical literature does not support the continuation of antibiotics until all drains or catheters are removed and provide no evidence of benefit when they are continued past 24 hours. In ideal case scenario, there should be a gap between blood transfusion \& surgery during which patient should be encouraged to take a balanced diet \& multi-nutrient supplementation, so that the body is healthy for wound healing at the time of surgery.

\section{REFERENCES}

1. Kui-Hin Liau, Khin-Thanda Aung, Nelson Chua, Choon-Kiat Ho, Chung-Yip Chan, et al. Surgical Infections. April 2010, 11(2): 151-159. doi:10.1089/sur.2008.081.

2. Kirkland KB, et al., The impact of surgical-site infections in the 1990s: Attributable mortality, excess length of hospitalization, and extra costs. Infect Control Hosp Epidemiol. Nov 1999;20(11):722-4.

3. Mangram AJ, et al., Guideline for prevention of surgical site infection. Centers for Disease Control and Prevention, Hospital Infection Control Practices Advisory Committee, Atlanta GA. 1999.

DOI: 10.5455/2320-1770.ijrcog20131203

Cite this article as: Mahana S, Biswas S. An analytical study on wound dehiscence and related factors. Int J Reprod Contracept Obstet Gynecol 2013;2:506-8. 